\title{
Tissue distribution of the laminin $\beta 1$ and $\beta 2$ chain during embryonic and fetal human development
}

\author{
Matthias Roediger • Nicolai Miosge • \\ Nikolaus Gersdorff
}

Received: 6 April 2010/Accepted: 4 June 2010/Published online: 15 June 2010

(C) The Author(s) 2010. This article is published with open access at Springerlink.com

\begin{abstract}
Laminins are the major glycoproteins present in all basement membranes. Previously, we showed that perlecan is present during human development. Although an overview of mRNA-expression of the laminin $\beta 1$ and $\beta 2$ chains in various developing fetal organs is already available, a systematic localization of the laminin $\beta 1$ and $\beta 2$ chains on the protein level during embryonic and fetal human development is missing. Therefore, we studied the immunohistochemical expression and tissue distribution of the laminin $\beta 1$ and $\beta 2$ chains in various developing embryonic and fetal human organs between gestational weeks 8 and 12 . The laminin $\beta 1$ chain was ubiquitously expressed in the basement membrane zones of the brain, ganglia, blood vessels, liver, kidney, skin, pancreas, intestine, heart and skeletal system. Furthermore, the laminin $\beta 2$ chain was present in the basement membrane zones of the brain, ganglia, skin, heart and skeletal system. The findings of this study support and expand upon the theory that these two laminin chains are important during human development.
\end{abstract}

Keywords Laminin - Basement membrane .

Tissue distribution · Human embryogenesis .

Immunohistochemistry

\section{Introduction}

The formation and maintenance of normal epithelial organization requires a basement membrane (Ekblom

M. Roediger · N. Miosge · N. Gersdorff $(\varangle)$

Department of Prosthodontics, Tissue Regeneration Work

Group, Georg-August-University Goettingen, Robert-Koch-Str.

40, 37075 Goettingen, Germany

e-mail: ngersdo@gwdg.de
1989; Virtanen et al. 1995a, b). Basement membranes are thin, specialized structures surrounding and separating layers of cells from different lineages. Basement membranes first appear during the blastocyst stage, between the primitive endoderm and the inner cell mass (Timpl and Brown 1996). They are the earliest extracellular matrices (ECM) produced during embryogenesis (Graham and Lehtonen 1979). At this stage, all main basement membrane components are synthesized, including laminin, nidogen, perlecan and collagen type IV (Leivo et al. 1980). Although basement membranes at various body sites are similar on the ultrastructural level (Merker 1994), there is evidence for their organ-specific heterogeneity (Ljubimov et al. 1995; Hallmann et al. 2005; Roediger et al. 2009). Though the molecular basis for such heterogeneity is not yet fully defined, many studies have shown organ-specific expression of the main basement membrane components, such as laminins (Glukhova et al. 1993; Virtanen et al. 1995a, b; Otonkoski et al. 2008).

The laminin family of glycoproteins is a major constituent of the basement membrane (Timpl 1996). During metazoan embryogenesis, laminins are required for basement membrane assembly and cell polarization, and have subsequent effects on cell survival and tissue organization (Li et al. 2003). In addition to their role in the assembly and architectural integrity of the basement membrane, laminins interact with cells to influence proliferation, differentiation, adhesion, and migration processes. In mammals, there are at least 15 laminins, each an $\alpha_{\mathrm{x}} \beta_{\mathrm{y}} \gamma_{\mathrm{z}}$ glycoprotein heterotrimer derived from five $\alpha$, three $\beta$, and three $\gamma$ subunits (Sasaki and Timpl 1999; Colognato and Yurchenco 2000; Libby et al. 2000). In 2005, a new heterotrimer identification system was introduced, using three Arabic numerals based on the $\alpha, \beta$, and $\gamma$ chain numbers (Aumailley et al. 2005). The earliest-expressed laminins during mammalian 
embryogenesis are laminin-111 and laminin-511, which show widespread expression and are crucial during mammalian embryonic development (Li et al. 2003). These two laminins mostly overlap in developmental expression and function, but only laminin-111 appears to be essential during the periimplantation period (Smyth et al. 1999).

We have previously shown that perlecan is present during embryonic and fetal human development, particularly at those stages of human development when epithelial-mesenchymal interactions occur (Roediger et al. 2009). In this work, we studied the immunohistochemical expression and tissue distribution of the laminin $\beta 1$ and laminin $\beta 2$ chains in various developing embryonic and fetal human organs between gestational weeks (gw) 8 and 12. Up to now, distribution of the laminin $\beta 1$ chain during human embryogenesis has generally been examined during late stages of fetal development, i.e., from gw 12 onwards. During this later stage, there is evidence for expression in the kidney (Virtanen et al. 1995a), several parts of the nervous system (Jaakola et al. 1993), pancreas, heart and skin (Iivanainen et al. 1995). However, laminin $\beta 1$ chain expression in skeletal muscle (Wewer et al. 1997) and smooth muscle cells in the aorta and intestine (Glukhova et al. 1993) could only be found during gw 10. Laminin $\beta 2$ chain expression was detected in the choroid plexus, skin, heart and pancreas during gw 17-19 (Iivanainen et al. 1995) and was shown not to be expressed before gw 9 in the lens capsule of the eye (Byström et al. 2006).

\section{Materials and methods}

\section{Tissue sources}

Aborted human embryos and fetuses were obtained according to the regulations of the Ethics Committee of the Medical Faculty of the University of Goettingen, Germany. The cut-off point for the differentiation between embryos and fetuses has been defined as ranging from gw 8 to 9 (Moore 1982). We investigated three embryos of gestational week gw 8, three fetuses of gw 10, two fetuses of gw 11 and two fetuses of gw 12. The ages were determined according to Carnegie stages (O'Rahilly and Müller 1987). No malformations or abnormalities were observed in these specimens. The abortion procedure leads to the destruction of much of the embryonic tissue; our results are, therefore, limited to those tissues we were able to follow to completion.

\section{Tissue processing}

The abortion material was transported to the laboratory in a histidine-tryptophane-ketoglutarate solution at $4{ }^{\circ} \mathrm{C}$ to ensure good preservation of the tissues (Bretschneider 1980; Koelling et al. 2006) and were fixed in $3.7 \%$ paraformaldehyde in phosphate buffer, $\mathrm{pH} 7.2$, at $4^{\circ} \mathrm{C}$ for $24 \mathrm{~h}$. The tissues were then serially dehydrated in ethanol from 30 to $100 \%$ and embedded in paraffin according to standard protocols (Gersdorff et al. 2005). Serial sections of $5 \mu \mathrm{m}$ thickness were cut with a Reichert's microtome. Every fifth section was stained with hematoxylin and eosin (HE) for topological orientation within the anatomical regions examined.

\section{Antibodies}

Rat monoclonal antibodies against the laminin $\beta 1$ chain were purchased from Chemicon International (Temecula, USA; catalogue number: MAB1928). An affinity purified rabbit anti-mouse antiserum specific for laminin $\beta 2 \mathrm{IV}$ was used to detect the laminin $\beta 2$ chain and has been shown not to cross-react with the $\beta 1$ chain (Sasaki et al. 2002). The secondary antibodies used for the light microscopic immunostaining were purchased from Dakopats (Hamburg, Germany).

\section{Immunohistochemistry}

Immunoperoxidase staining was performed on paraffinembedded tissue sections as follows: Tissues were deparaffinized, rehydrated and rinsed for $10 \mathrm{~min}$ in phosphate buffered saline (PBS), $\mathrm{pH}$ 7.2. Endogenous peroxidase was inhibited with a solution of $3 \% \mathrm{H}_{2} \mathrm{O}_{2}$ in methanol for $45 \mathrm{~min}$ in the dark (Koelling et al. 2006). The sections were pretreated for $5 \mathrm{~min}$ with $10 \mu \mathrm{g} / \mathrm{ml}$ protease XXIV (Sigma Deisenhofen, Germany). The antibodies against the laminin $\beta 1$ and $\beta 2$ chains were used at a 1:100 dilution in PBS/BSA $1 \%$ and incubated for $1 \mathrm{~h}$ at room temperature. The tissues were rinsed in PBS for 10 min following each of the steps. The secondary antibody was applied at a 1:50 dilution in PBS/BSA. A standard peroxidase-antiperoxidase procedure followed, applying a peroxidase-coupled goat-anti-rabbit antibody (Dako, Hamburg, Germany) at a dilution of 1:150 in PBS for $30 \mathrm{~min}$ at room temperature. The sections were counterstained with hematoxylin. Negative controls omitted the primary antibody.

\section{Results}

A list of our results regarding the tissue distribution of the laminin $\beta 1$ chain is given in Table 1 and Fig. 1. Comparative findings regarding the tissue distribution of the laminin $\beta 2$ chain are shown in Table 2 and Fig. 2. Results for the developing human eye are mentioned in text below and shown in Fig. 3. 


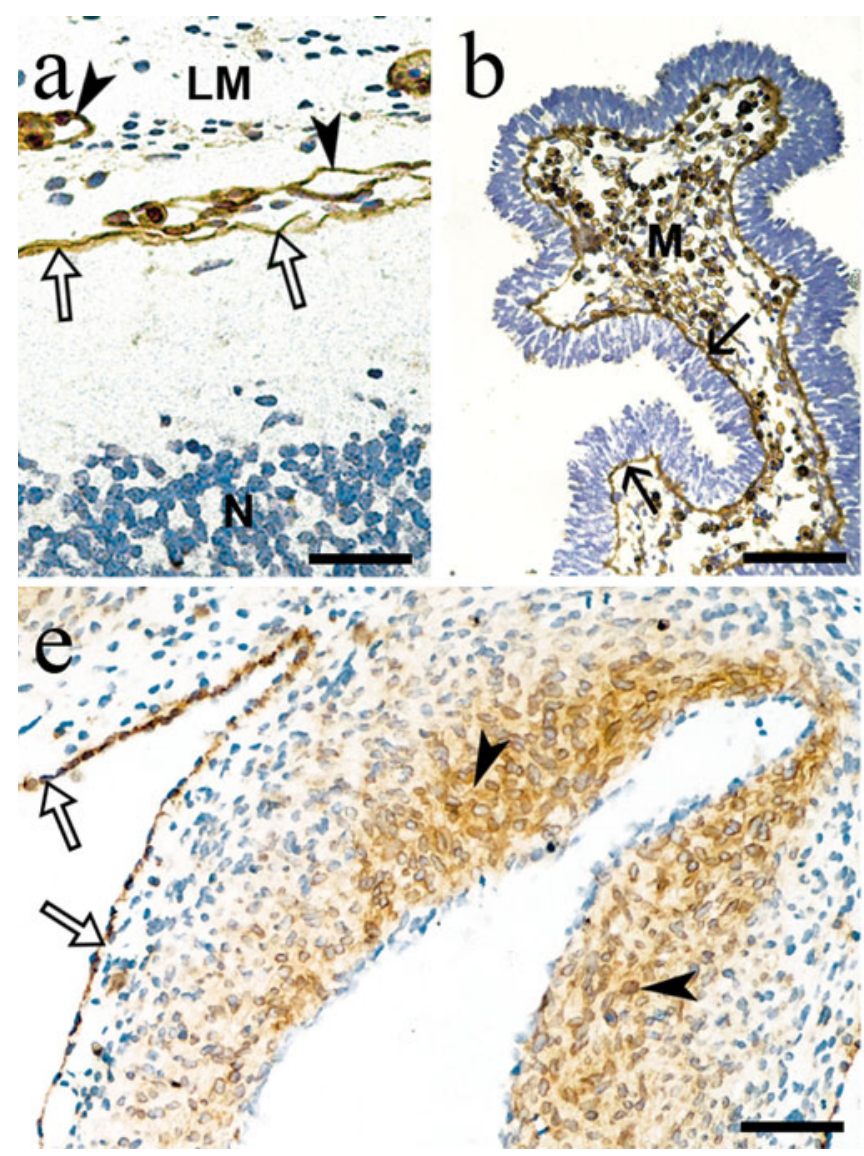

Fig. 1 Localization of the laminin $\beta 1$ chain during gw 8 and 9 in human embryogenesis. a Immunostaining for laminin $\beta 1$ chain in BMZs of neuroectoderm (open arrows) and capillaries (arrowheads). Loose mesenchyme cells $(L M)$ and neuronal cells $(N)$ showed no staining for the laminin $\beta 1$ chain. b BMZs (arrows) and mesenchymal cells $(M)$ of the choroid plexus exhibited staining for the laminin $\beta 1$ chain. $\mathbf{c}$ Localization of the laminin $\beta 1$ chain in BMZs of a sinusoid $(S)$ of developing liver (arrows). Hepatocytes (asterisk) were negative

\section{Neuronal system}

The choroid plexus consists of many capillaries and is the part of the ventricular system where cerebrospinal fluid is produced. The invagination of the choroid plexus in the developing telencephalon starts at gw 5 (Sadler 2005). We found the laminin $\beta 1$ and laminin $\beta 2$ chains in basement membrane zones (BMZs) and mesenchymal cells of choroid plexus at gw 8 and 9. BMZs of the neuroectoderm and BMZs of capillaries stained positive for both laminin chains from gw 8, whereas no staining was detected for either laminin chain in neuroectodermal cells.

The laminin $\beta 1$ and $\beta 2$ chain expression was found in the endoneurium of peripheral ganglia and BMZs of capillaries from gw 8 onwards. Neuronal cells were negative for the laminin $\beta 1$ and laminin $\beta 2$ chains at all stages examined.

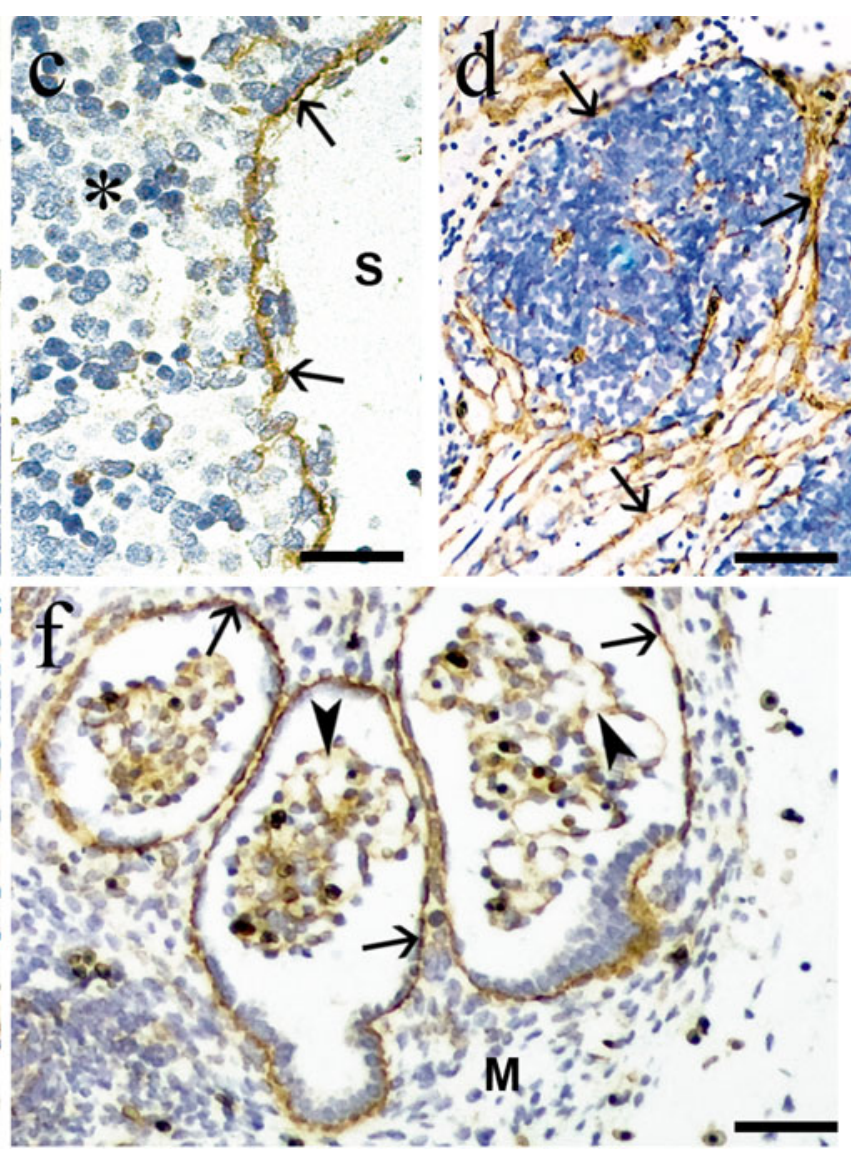

for the laminin $\beta 1$ staining at gw 8. d Immunostaining for laminin $\beta 1$ chain in the endoneurium of spinal ganglia (arrows). e The laminin $\beta 1$ chain in the ECM of cardiomyocytes (arrowheads) and in BMZs of pericardium. f Detection of the laminin $\beta 1$ chain in Bowman's capsule (arrows) and in glomerular basement membranes (arrowheads) of the developing kidney. Mesenchymal cells $(M)$ showed no staining for the laminin $\beta 1$ chain. Bars $15 \mu \mathrm{m}$ in $\mathbf{a}, \mathbf{b}, \mathbf{c}, \mathbf{d}, \mathbf{e}$, and $\mathbf{f}$

Blood vessels

The differentiation of angioblasts into endothelial cells begins in the visceral mesoderm at gw 3 (O'Rahilly and Müller 1996). Endothelial BMZs of arteries and veins, as well as BMZs of capillaries, between gw 8 and 12 stained positive for the laminin $\beta 1$ chain.

\section{Liver}

The development of the liver is initiated by the budding of entodermal cells from the distal end of the foregut (O'Rahilly and Müller 1996). The laminin $\beta 1$ chain was detected in BMZs from sinusoids from gw 8 to 12 . Hepatocytes did not express the laminin $\beta 1$ chain before $\mathrm{gw}$ 10. The presence of the laminin $\beta 1$ chain was detected at gw 12 . 


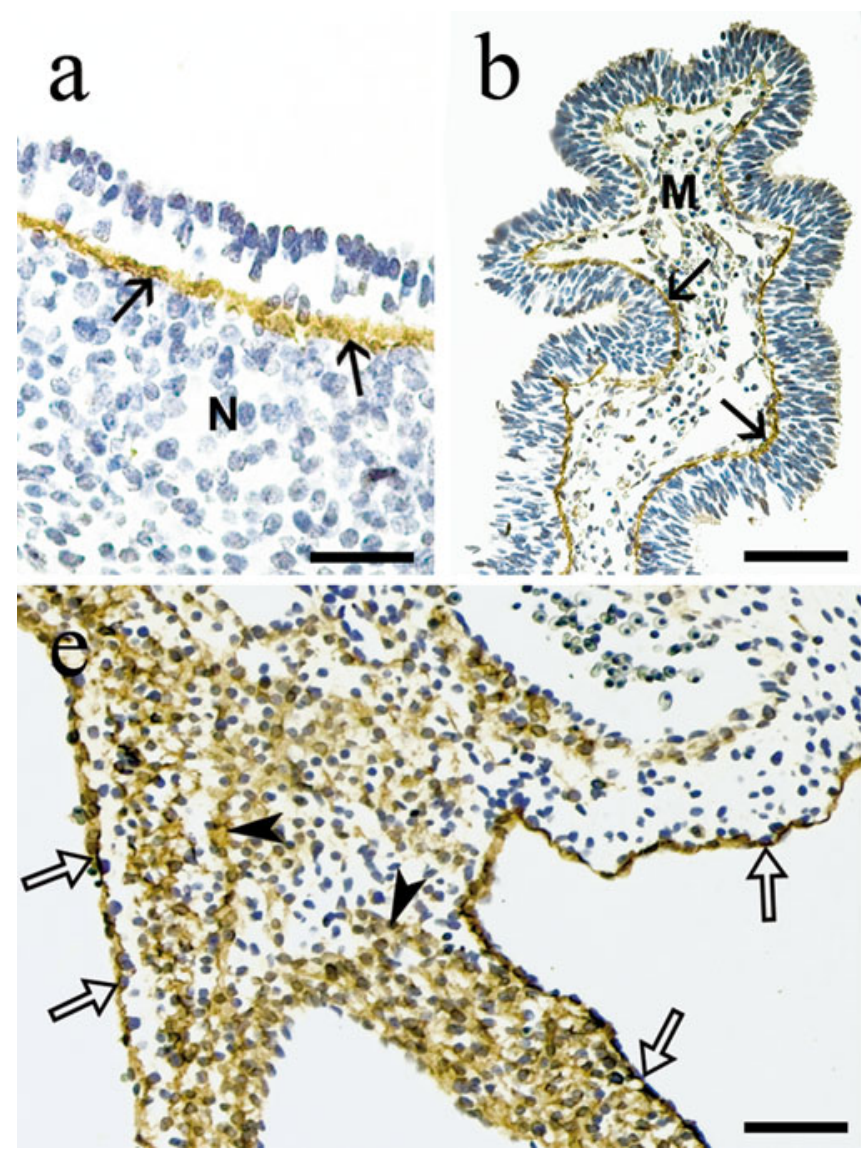

Fig. 2 Localization of the laminin $\beta 2$ chain during gw 8 and 9 in human embryogenesis. a BMZs of neuroectoderm (arrows) were positive for immunostaining of the laminin $\beta 2$ chain, whereas neuroectodermal cells $(N)$ showed no staining. b BMZs (arrows) of the choroid plexus exhibited staining for the laminin $\beta 2$ chain, whereas mesenchymal cells $(M)$ showed only weak staining. c Localization of the laminin $\beta 2$ chain in the BMZ of a capillary of neuronal tissue (arrows). d Immunostaining for the laminin $\beta 2$ chain

\section{Kidney}

During kidney development, three renal systems evolve: the pronephros, the mesonephros and the metanephros (Saxen and Sariola 1987). The Bowman's capsule and BMZs of the glomeruli and tubules stained positive for the laminin $\beta 1$ chain at all developmental stages examined, whereas mesenchymal cells exhibited no expression of the laminin $\beta 1$ chain.

\section{Skin}

Skin development starts from a separation of the ectodermal and mesodermal compartments. The epidermis derives from the ectoderm, whereas the dermis derives from the mesoderm (Smith and Holbrook 1986). In BMZs of dermal-epidermal junctions and capillaries, the laminin $\beta 1$ chain was expressed from gw 8 onwards, and positive

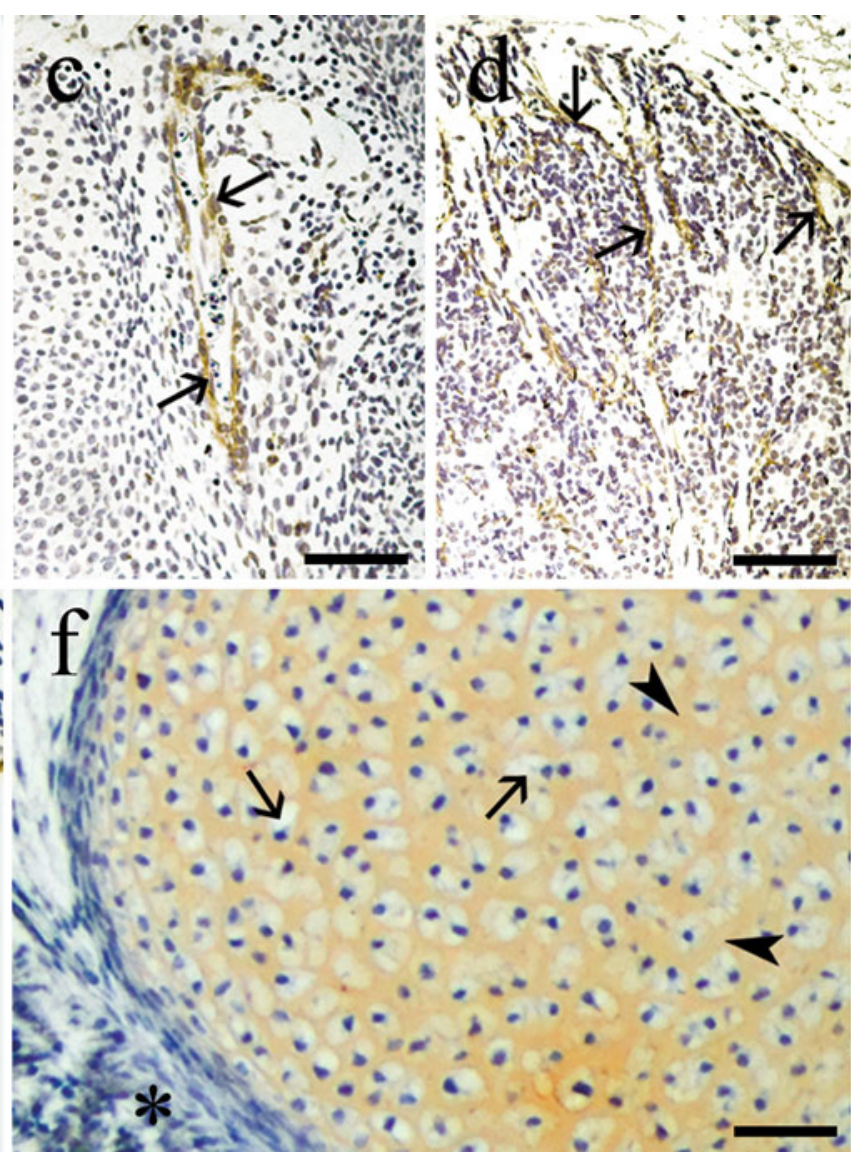

in the endoneurium of spinal ganglia (arrows). e The laminin $\beta 2$ chain in the ECM of cardiomyocytes (arrowheads) and in BMZs of periand endocardium (open arrows). $\mathbf{f}$ The interterritorial matrix (arrowheads) of chondrocytes showed positive staining for the laminin $\beta 2$ chain, whereas the proliferating chondrocytes themselves (arrows) exhibited no staining. Skeletal muscle cells (asterisk) were negative for the laminin $\beta 2$ chain. Bars $15 \mu \mathrm{m}$ in $\mathbf{a}, \mathbf{b}, \mathbf{c}, \mathbf{d}, \mathbf{e}$, and $\mathbf{f}$

staining for the laminin $\beta 2$ chain could be shown during $\mathrm{gw}$ 11. Cells of the loose mesenchyme were negative for the laminin $\beta 1$ and $\beta 2$ chain staining at all developmental stages examined.

\section{Pancreas}

BMZs of the developing exocrine gland were positive for the laminin $\beta 1$ chain from gw 8 onwards. Furthermore, BMZs of glandular capillaries were positive for the laminin $\beta 1$ chain staining, whereas epithelial cells exhibited no staining for the laminin $\beta 1$ chain.

Intestine

The early foregut forms by gw 4 . The musculature and connective tissues of the gastro-intestinal tract derive from the surrounding mesenchyme (O'Rahilly and Müller 
Table 1 Light microscopic immunostaining for the laminin $\beta 1$ chain in human specimens from gw 8 to 12

\begin{tabular}{lllll}
\hline Developing organ & \multicolumn{4}{l}{ Gestational week } \\
\cline { 2 - 5 } & $8 / 9$ & 10 & 11 & 12 \\
\hline
\end{tabular}

\section{Brain}

$\mathrm{BMZ}$ of neuroectoderm

Neuroectodermal cells

BMZ of capillaries

$\mathrm{BMZ}$ of choroid plexus

Mesenchyme of choroid plexus

Ganglia

Neuronal cells

Endoneurium

BMZ of capillaries

Blood vessels

BMZ of endothelium

Liver

Hepatocytes

$\mathrm{BMZ}$ of sinusoids

$\mathrm{BMZ}$ of mesothelium

Kidney

BMZ of glomeruli

$\mathrm{BMZ}$ of tubules

Bowman's capsule

Mesenchyme

Skin

Epidermis

Dermal-epidermal BMZ

Dermis

BMZ of capillaries

Mesenchyme

Pancreas

Glands

BMZ of glands

BMZ of capillaries

Intestine

Epithelium

BMZ of epithelium

Mesenchyme

BMZ of capillaries

Heart

Cardiomyocytes

ECM of cardiomyocytes

$\mathrm{BMZ}$ of endo-/pericardium

BMZ of capillaries

Skeletal system

Cartilage

Bone

BMZ of skeletal muscle cells

$\begin{array}{llll}+ & + & + & \varnothing \\ - & - & - & \varnothing \\ + & + & + & \varnothing \\ + & \varnothing & \varnothing & \varnothing \\ + & \varnothing & \varnothing & \varnothing\end{array}$

$-\varnothing \varnothing \quad$

$+\varnothing \varnothing+$

$+\varnothing \varnothing+$

$+\quad+\quad+$

$\begin{array}{lll}+ & + \\ & +\end{array}$

$-\quad+\quad+$

$+\quad+\varnothing+$

$-\varnothing \varnothing$

$+\quad+\quad+$

$+\varnothing+$

$+\varnothing+$

- $\varnothing-$

$-$

$\begin{array}{llll}- & - & -\end{array}$

$+\quad+\quad+$

$\begin{array}{llll}+ & - & -\end{array}$

$+\quad+\quad+$

$\begin{array}{llll}+ & - & -\end{array}$

$-\quad-\quad-\quad-$

$+\quad+\quad+$

$+\quad+\quad+$

$\begin{array}{llll}- & - & - & -\end{array}$

$+\quad+\quad+$

$+\quad+\quad+$

$+\quad+\quad+$

$-\frac{1}{2}+$

$\begin{array}{llll}- & \varnothing & -\end{array}$

$+\varnothing+$

$+\varnothing+$

$+\varnothing+$

$\overline{(+) \text { positive reaction; ( }) \text { negative reaction; } \varnothing \text { tissues not available }}$
Table 2 Light microscopic immunostaining for the laminin $\beta 2$ chain in human specimens from gw 8 to 11 (tissues of other gestational weeks were not available)

\begin{tabular}{lll}
\hline Developing organ & \multicolumn{2}{l}{ Gestational week } \\
\cline { 2 - 3 } & $8 / 9$ & 11 \\
\hline
\end{tabular}

\section{Brain}

$\mathrm{BMZ}$ of neuroectoderm

$+\varnothing$

Neuroectodermal cells

$-\varnothing$

BMZ of capillaries

$+\varnothing$

BMZ of choroid plexus

$+\varnothing$

Mesenchyme of choroid plexus

$+$

Ganglia

Neuronal cells

$\begin{array}{ll}- & \varnothing \\ + & \varnothing \\ + & \varnothing\end{array}$

BMZ of capillaries

Skin

Epidermis

Dermal-epidermal BMZ

Dermis

BMZ of capillaries

Mesenchyme

Heart

Cardiomyocytes

ECM of cardiomyocytes

$\mathrm{BMZ}$ of endo-/pericardium

$\mathrm{BMZ}$ of capillaries

$\varnothing \quad-$

Skeletal system

$\begin{array}{lll}\text { Cartilage } & + & \varnothing \\ \text { Bone } & \varnothing & \varnothing \\ \text { BMZ of skeletal muscle cells } & - & \varnothing\end{array}$

$\overline{(+) \text { positive reaction; (-) negative reaction; } \varnothing \text { tissues not available }}$

1996). In the developing intestine, the laminin $\beta 1$ chain was detected in BMZs of capillaries and in the mesenchyme from gw 8 onwards. The laminin $\beta 1$ chain was absent in epithelial cells of the intestine at all stages investigated.

Heart

The early heart anlage consists of two compartments separated from each other by the cell-free, homogeneous cardiac jelly (CJ): the endocardial tube and the developing myocardial layer, both already present at gw 4. The CJ also surrounds individual myocytes (Wenink 1976). The laminin $\beta 1$ chain was first detected at gw 8 in BMZs of the endo- and the pericardium, as well as BMZs of capillaries, and was present until gw 12. Developing cardiomyocytes were negative for the laminin $\beta 1$ chain 


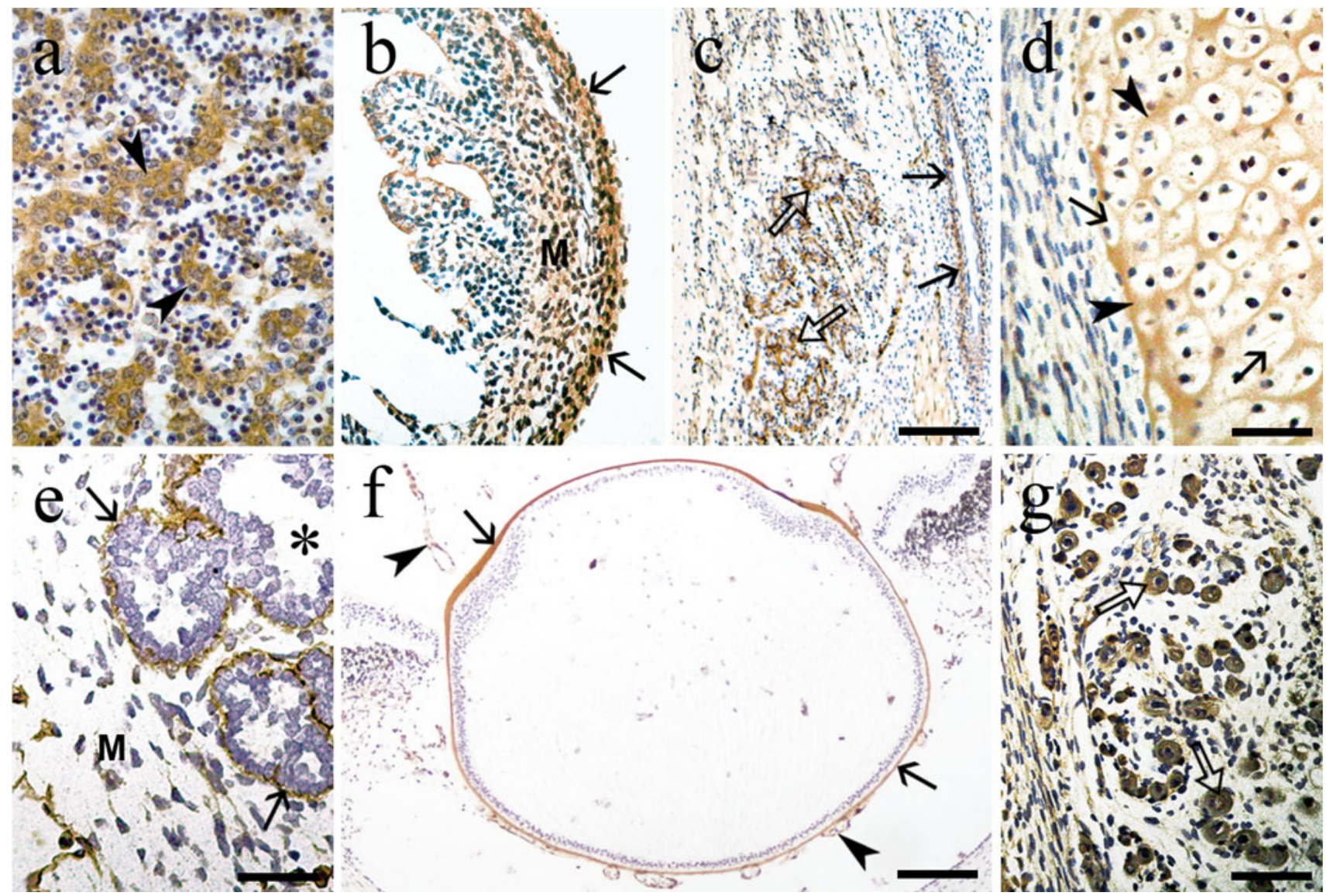

Fig. 3 Localization of the laminin $\beta 1$ chain in various organs during human embryogenesis. a At gw 10, hepatocytes of developing liver revealed distinct staining for the laminin $\beta 1$ chain (arrowheads). b The laminin $\beta 1$ chain was detected in mesenchymal cells $(M$, arrows) of the intestine at gw 12. $\mathbf{c}$ Positive staining for the laminin $\beta 1$ chain was seen in BMZs of skeletal muscle cells (open arrows) and in BMZs of capillaries (arrows) at gw 12. d Staining for the laminin $\beta 1$ chain in the pericellular and interterritorial matrix (arrowheads) of rib cartilage anlagen at gw 12. Chondrocytes (arrows) revealed no specific staining for the laminin $\beta 1$ chain. e At gw 8, BMZs of glands of the developing pancreas exhibited positive staining for the laminin $\beta 1$ chain (arrows). The pancreatic gland itself (asterisk), and mesenchymal cells $(M)$, were negative for the laminin $\beta 1$ chain. $\mathbf{f}$ Detection of the laminin $\beta 1$ chain in the lens capsule of the eye (arrows) and BMZs of capillaries (arrowheads). g BMZs of transversal sections of skeletal muscle cells showed positive staining for the laminin $\beta 1$ chain (open arrows). Bars $15 \mu \mathrm{m}$ in $\mathbf{a}, \mathbf{b}, \mathbf{d}, \mathbf{e}$, and $\mathbf{g} ; 60 \mu \mathrm{m}$ in $\mathbf{c}$ and $\mathbf{f}$

Eye

staining, but the ECM of the cardiomyocytes revealed positive staining.

Additionally, the expression of the laminin $\beta 2$ chain during gw 8 and 9 had a similar pattern as the distribution of the laminin $\beta 1$ chain during the same period.

\section{Skeletal system}

The laminin $\beta 1$ chain is present in developing bone. In cartilage, we found the laminin $\beta 1$ chain from gw 10 onwards, whereas the detection of the laminin $\beta 2$ chain was limited to gw 8 and 9, another difference between the embryonic distribution of these two laminin chains. BMZs of the skeletal muscle cells were positive for staining of the laminin $\beta 1$ chain from gw 10 to 12 , whereas the laminin $\beta 2$ chain was not detected.
The laminin $\beta 1$ chain was detected in the lens capsule of the developing eye from gw 10 to 12 . The laminin $\beta 2$ chain was only detected in the lens capsule during gw 10.

\section{Discussion}

Laminin is the first extracellular matrix protein to appear during embryonic development, first detectable in the 16-cell (morula) embryo (Leivo et al. 1980). From the blastocyst stage onwards, laminin or its subunits are required for development, maintenance of cellular polarity and compaction of the cells (Timpl et al. 1983; Smyth et al. 1999). 
An overview of mRNA-expression of the laminin $\beta 1$ and $\beta 2$ chains in various developing fetal organs (gw 1719) has been provided by Iivanainen et al. (1995). In organs like the eye, choroid plexus, kidney, pancreas and skin, both chains showed similar expression patterns. We identified the laminin $\beta 1$ and $\beta 2$ chain proteins in the endocardium of the heart and in the choroid plexus. Additionally, laminin $\beta 1$ chain mRNA was detected in the dermis of the skin and endothelial cells of blood vessels (Iivanainen et al. 1995). We found that BMZs of these tissues contain the laminin $\beta 1$ chain protein. These findings support the idea that the structural components of the subepithelial basement membrane are produced both by the epithelial cells and by stromal fibroblasts of the upper dermis (Iivanainen et al. 1995).

Localization of laminin $\beta 1$ chain mRNA to the glomeruli of the kidney could not be demonstrated, but we found positive staining for the protein in the relevant BMZs. Miner (1998) highlighted the important role of the laminin chains $\beta 1$ and $\beta 2$ during the development of the kidney. In the maturing glomeruli of wild type mice, the laminin $\beta 2$ chain is gradually replaced by the laminin $\beta 1$ (Noakes et al. 1995). This is in agreement with our results, which show the presence of the laminin $\beta 1$ chain in BMZs of glomeruli and tubuli in the developing kidney from gw 8 to 12 during human development.

We found the laminin $\beta 1$ chain in the lens capsule of the eye between gw 10 and 12, and the laminin $\beta 2$ chain at gw 10, as did Byström et al. (2006) up to gw 20. Furthermore, another study demonstrated that laminin $\beta 1$ is essential for BM integrity in the zebrafish eye (Lee and Gross 2007).

We have previously shown that perlecan is present during embryonic and fetal human development in BMZs of blood vessels and capillaries in various organs (Roediger et al. 2009). Now, we present evidence for a similar localization of the laminin $\beta 1$ chain from embryonic gw 8 onwards in BMZs of endothelial cells of blood vessels. The laminin $\beta 1$ chain has been described in human smooth muscle cells of fetal developing vasculature and intestine up to gw 22. Based on these results, an important role for laminins in the maintenance of differentiated smooth muscle cells has been postulated (Glukhova et al. 1993). Additionally, we found positive staining for the laminin $\beta 1$ chain in BMZs of capillaries and in the mesenchyme from gw 8 to 12 , demonstrating the presence of this protein in the developing embryonic and fetal gut. Another study showed the omnipresent localization of the laminin $\beta 1$ chain in all BMZs of human adult gastric mucosa (Virtanen et al. 1995b).

In skeletal muscle cells, we found the laminin $\beta 1$ chain in BMZs between gw 10 and 12, whereas the presence of the laminin $\beta 2$ chain could not be shown before gw 15 (Wewer et al. 1997). This indicates that the laminin $\beta 2$ chain is only present in later stages of skeletal muscle development.

Previous studies demonstrated the involvement of laminin fragments in the development of cartilage. In human fetal cartilage (gw 17 and 24), a strong pericellular immunohistochemical reaction for laminin-111 was shown (Dürr et al. 1996). In embryo chick sternum and mouse limb bud, laminin $\beta 1$ and $\beta 2$ chains are present in the cytoplasm of chondrocytes (Lee et al. 1997). We found laminin $\beta 1$ present in cartilage from gw 10 onwards, but not during gw 8 and 9 . This suggests that the laminin $\beta 1$ chain does not play a role in human cartilage development until the fetal stage. According to the results of our study, the laminin $\beta 2$ chain could only be detected during gw 8 and 9 , indicating a laminin $\beta$ switch in which laminin $\beta 2$ is eventually replaced by laminin $\beta 1$ during cartilage development, as has been demonstrated in the glomeruli of the kidney (Noakes et al. 1995).

In our current work, laminin $\beta 1$ and $\beta 2$ chains were detected in various neuronal tissues. The first laminin subunits detectable within the human nervous system are $\beta 1$ and $\beta 2$ chains, present in BMZs of Schwann cells at gw 11, and in the perineurium at gw 17 (Jaakola et al. 1993). Based on a study of the development of the rat central nervous system, it has been postulated that laminin $\beta 1$ has an influence on rat nervous system development (Hunter et al. 1992).

Taken together, our data demonstrate the ubiquitous presence of the laminin $\beta 1$ chain during human embryonic and fetal development from gw 8 to 12 . The laminin $\beta 2$ chain was not as widely distributed during these developmental stages. In some organs, such as kidney or cartilage, a chain switch from the laminin $\beta 2$ chain to the $\beta 1$ chain seems to be a common developmental pattern.

Acknowledgments We would like to thank Dr. Takako Sasaki (Shriners Hospital in Portland, Oregon) for the laminin $\beta 2$ chain antibody.

Open Access This article is distributed under the terms of the Creative Commons Attribution Noncommercial License which permits any noncommercial use, distribution, and reproduction in any medium, provided the original author(s) and source are credited.

\section{References}

Aumailley M, Bruckner-Tuderman L, Carter WG, Deutzmann R, Edgar D, Ekblom P, Engel J, Engvall E, Hohenester E, Jones JCR, Kleinman HK, Marinkovich MP, Martin GR, Mayer U, Meneguzzi G, Miner JH, Miyazaki K, Patarroyo M, Paulsson M, Quaranta V, Sanes JR, Sasaki T, Sekiguchi K, Sorokin LM, Talts JF, Tryggvason K, Uitto J, Virtanen I, von der Mark K, Wewer UM, Yamada Y, Yurchenco PD (2005) A simplified laminin nomenclature. Matrix Biol 24:326-332

Bretschneider HJ (1980) Myocardial protection. Thorac Cardiovasc Surg 28:295-302 
Byström B, Virtanen I, Rouselle P, Gullberg D, Pedrosa-Domellöf F (2006) Distribution of laminins in the developing human eye. Invest Ophtalmol Vis Sci 47:777-785

Colognato H, Yurchenco PD (2000) Form and function: the laminin family of heterotrimers. Dev Dyn 218:213-234

Dürr J, Lammi P, Goodman SL, Aigner T, von der Mark K (1996) Identification and immunolocalization of laminin in cartilage. Exp Cell Res 222:225-233

Ekblom P (1989) Developmentally regulated conversion of mesenchyme to epithelium. FASEB J 3:2141-2150

Gersdorff N, Kohfeldt E, Sasaki T, Timpl R, Miosge N (2005) Laminin gamma3 chain binds to nidogen and is located in murine basement membranes. J Biol Chem 280:22146-22153

Glukhova M, Koteliansky V, Fondacci C, Marotte F, Rappaport L (1993) Laminin variants and integrin laminin receptors in developing and adult human smooth muscle. Dev Biol 157:437-447

Graham CF, Lehtonen E (1979) Formation and consequences of cell patterns in preimplantation mouse development. J Embryol Exp Morphol 49:277-294

Hallmann R, Horn N, Selg M, Wendler O, Pausch F, Sorokin LM (2005) Expression and function of laminins in the embryonic and mature vasculature. Physiol Rev 85:979-1000

Hunter DD, Llinas R, Ard M, Merlie JP, Sanes JP (1992) Expression of s-laminin and laminin in the developing rat central nervous system. J Comp Neurol 323:238-251

Iivanainen A, Vuolteenaho R, Sainio K, Eddy R, Shows TB, Sariola H, Tryggvason K (1995) The human laminin beta 2 chain (Slaminin): structure, expression in fetal tissues and chromosomal assignment of the LAMB2 gene. Matrix Biol 14:489-497

Jaakola S, Savunen O, Halme T, Uitto J, Peltonen J (1993) Basement membranes during development of human nerve: Schwann cells and perineurial cells display marked changes in their expression profiles for laminin subunits and beta 1 and beta 4 integrins. J Neurocytol 22:215-230

Koelling S, Clauditz TS, Kaste M, Miosge N (2006) Cartilage oligomeric matrix protein is involved in human limb development and in the pathogenesis of osteoarthritis. Arthritis Res Ther 8:R56

Lee J, Gross JM (2007) Laminin beta 1 and gamma 1 containing laminins are essential for basement membrane integrity in the zebrafish eye. Invest Ophtalmol Vis Sci 48:2483-2490

Lee SK, Malpeli M, Cancedda R, Utani A, Yamada Y, Kleinman HK (1997) Laminin chain expression by chick chondrocytes and mouse cartilaginous tissues in vivo and in vitro. Exp Cell Res 236:212-222

Leivo I, Vaheri A, Timpl R, Wartiovaara J (1980) Appearance and distribution of collagens and laminin in the early mouse embryo. Dev Biol 76:100-114

Li S, Edgar D, Fässler R, Wadsworth W, Yurchenco PD (2003) The role of laminin in embryonic cell polarization and tissue organization. Dev Cell 4:613-624

Libby RT, Champliaud MF, Claudepierre T, Xu Y, Gibbons EP, Koch M, Burgeson RE, Hunter DD, Brunken WJ (2000) Laminin expression in adult and developing retinae: evidence of two novel CNS laminins. J Neurosci 20:6517-6528

Ljubimov AV, Burgeson RE, Butkowski RJ, Michael AF, Sun TT, Kenney MC (1995) Human corneal basement membrane heterogeneity: topographical differences in the expression of type IV collagen and laminin isoforms. Lab Invest 72:461-473

Merker HJ (1994) Morphology of the basement membrane. Microsc Res Technol 28:95-124

Miner JH (1998) Developmental biology of glomerular basement membrane components. Curr Opin Nephrol Hypertens 7:13-19

Moore KL (1982) The developing human. Saunders, Philadelphia

Noakes PG, Miner JH, Gautam M, Cunningham JM, Sanes JR, Merlie JP (1995) The renal glomerulus of mice lacking s-laminin/ laminin $\beta 2$ : nephrosis despite molecular compensation by laminin $\beta 1$. Nat Genet 10:400-406

O'Rahilly R, Müller F (1987) Developmental stages in human embryos. Including a revision of streeter's "horizon" and a survey of the Carnegie collection Carnegie Institution of Washington Publication 637 Washington

O’Rahilly R, Müller F (1996) Human embryology and teratology, 2nd edn. Wiley-Liss, New York, pp 149-157

Otonkoski T, Banerjee M, Korsgren O, Thornell LE, Virtanen I (2008) Unique basement membrane structure of human pancreatic islets: implications for beta-cell growth and differentiation. Diabetes Obes Metab 10:119-127

Roediger M, Kruegel J, Miosge N, Gersdorff N (2009) Tissue distribution of perlecan domains III and V during embryonic and fetal human development. Histol Histopathol 24:859-868

Sadler TW (2005) Embryology of neural tube development. Am J Genet C Semin Med Genet 135C:2-8

Sasaki T, Timpl R (1999) Guidebook to extracellular matrix, anchor, and adhesion proteins. Sambook and Tooze, Oxford, pp 434-443

Sasaki T, Mann K, Miner JH, Miosge N, Timpl R (2002) Domain IV of mouse laminin beta1 and beta2 chains. Eur J Biochem 269:431-442

Saxen L, Sariola H (1987) Early organogenesis of the kidney. Pediatr Nephrol 1:385-392

Smith LT, Holbrook KA (1986) Embryogenesis of the dermis in human skin. Pediatr Dermatol 3:271-280

Smyth N, Vatansever HS, Murray P, Meyer M, Frie C, Paulsson M, Edgar D (1999) Absence of basement membranes after targeting LAMC1 gene results in embryonic lethality due to failure of endoderm differentiation. J Cell Biol 144:151-160

Timpl R (1996) Macromolecular organization of basement membranes. Curr Opin Cell Biol 8:618-624

Timpl R, Brown JC (1996) Supramolecular assembly of basement membranes. BioEssays 18:123-132

Timpl R, Engel J, Martin GR (1983) Laminin-a multifunctional protein of basement membranes. Trends Biochem Sci 8:207-209

Virtanen I, Laitinen L, Korhonen M (1995a) Differential expression of laminin polypeptides in developing and adult human kidney. J Histochem Cytochem 43:621-628

Virtanen I, Tani T, Bäck N, Häppölä O, Laitinen L, Kiviluoto T, Salo J, Burgeson RE, Lehto VP, Kivilaakso E (1995b) Differential expression of laminin chains and their integrin receptors in human gastric mucosa. Am J Pathol 147:1123-1132

Wenink AC (1976) Development of the human cardiac conducting system. J Anat 121:617-631

Wewer UM, Thornell LE, Loechel F, Zhang X, Durkin ME, Amano S, Burgeson RE, Engvall E, Albrechtsen R, Virtanen I (1997) Extrasynaptic location of laminin beta 2 chain in developing and adult human skeletal muscle. Am J Pathol 151:621-631 